\title{
The Linkage between China's Foreign Direct Investment and Ghana's Building and Construction Sector Performance
}

\author{
Kwasi BOAKYE-GYASI ${ }^{*}$, Yao LI**
}

\begin{abstract}
Over the years, China has contributed immensely to the development process of Ghana through foreign direct investments; providing financial aids'improved management training skills, and the transfer of innovation and technological techniques. This research examines the relationship between China's foreign direct investment and Ghana's building and construction sector performance. By using a robust regression model, the results show that China's FDI in Ghana's building and construction sector has significant positive effect on the economic growth of Ghana due to strong increase in investors' confidence in the Ghanaian economy. Thus, FDI contributes to economic growth when there is an improvement of the infrastructure and operational skills of the local building and construction companies. This will lead to the increase of revenue for citizens who are employed in this sector and thus leading to the overall economic development of the country.
\end{abstract}

Keywords: Chinese FDI, Building and Construction, Sector Performance, Economic Growth, Housing Industry

Jel Code Classification: F21, F10, F23

UDC: 339.727.24(510):69(667)

DOI: https://doi.org/10.17015/ejbe.2016.018.05

\footnotetext{
*Corresponding Author. PhD Candidate, School of Management and Economics, University of Electronic Science and Technology of China, Chengdu, China. E-mail: kwasiboakyegyasi@hotmail.com

${ }^{* *}$ Associate Professor, School of Management and EconomicsUniversity of Electronic Science and Technology of China, Chengdu, China. E-mail: euvox@163.com

Copyright (C, 2016 International Ataturk Alatoo University.
} 


\section{Introduction}

According to the International Monetary Fund (1993), Foreign Direct Investment (FDI) is a cross-border investment made by a direct investor from country A with the objective of establishing a lasting interest in an incorporated enterprise in country B. Developing countries in recent times have identified economic growth as a key priority to strengthening their national economic system and it is reasonable to comprehend that, the global FDI inflows reached a $30 \%$ increase in 2007 at USD 1,979 trillion (UNCTAD, 2008). However, there was a downward trend in 2008 through 2009 as the global FDI decreased to USD 1,697 trillion in 2008 and USD 1,114 trillion in 2009 respectively. But in 2010, the global FDI increased by 5\% to reach USD 1,169 trillion. Borensztein et al (1998) stated that, the ratio of FDI to GDP in developing countries over the period 1970-1989 saw an increase of $1 \%$, which was linked with the GDP per capita growth of $0.4 \%$ to $0.7 \%$ increases. In addition, Sauvant (2007) acknowledges that, economic development creates a new environment for FDI and thus the purpose of FDI in economic growth is achieved through increased revenue by the recipient countries. In developing countries like Ghana, the building and construction sector is regarded as one of the major drivers of economic growth since this sector can effectively utilize human and material resources to develop and maintain infrastructures leading to improvement in economic efficiency. According to the Ghana Statistical Service (2015), the implementation of good macroeconomic policies in the building and construction sector saw the sector's contribution to GDP at high of13.2 percent in 2015 while the sector's share as a percentage of GDP was at a low figure of 5.7 percent in 2006. Mosaku et al (2006) indicates that, the building and construction sector of the economy is one of the many sectors of an economy used in measuring the GDP of any country and its effect on every other sector and so, over the past decade in Ghana, there has been substantial improvement in the building and construction sector as per its share of contribution to the overall GDP. Segments like electricity, water, and quarrying have made the impact of the sector much greater. Rameezdeen et al (2006) reveal that, the building and construction sector affects the economy at all levels through the generation of employment and incomes for the people of a country. Therefore, the building and construction sector is viewed as an important contributor to the process of growth and this sector as indicated by Lean (2001) has a strong linkage with other economic sectors as other sectors of the economy will experience the influence and as a result an increase or decrease in the wealth of a country.

Most countries in West Africa have enjoyed streams of FDI and many of those countries prefer FDI coming from China due to China's fast growing economy and their experience with FDI utilization and Ghana is no exception. According to the Ghana Investment Promotion Center (2013) reports, Ghana recorded USD 513.8 million from 2000 to 2012 as the total of Chinese investments. GIPC also stated that, China became the main source of FDI inflows to Ghana in 2009, and by the 
turn of 2010, more than 500 registered Chinese companies were undertaking projects in building and construction, manufacturing, and so on. Furthermore, the GIPC report acknowledges that, investments from Chinese companies in the building and construction sector reached a minimum of USD 60,000 in 2008 and a maximum of USD 64.41 million in 2010. Some notable completed public sector projects with Chinese aid in the building and construction sector includes: USD 15 million office complex building for the Ministry of Foreign Affairs and Regional Integration, USD 622 million development of Bui Hydro-Electric Power dam, USD 28 million construction of the $17 \mathrm{~km}$ Ofankor-Nsawam road network, and USD 6 billion Ghana Railway Project.

Many foreign firms' (especially Chinese companies) are expanding their operations to Ghana due to the stable political environment. The Institute for Economics and Peace (2012) rated Ghana as one of the most peaceful nations at the $42^{\text {nd }}$ position in the previous year rankings. Due to this, Ghana has seen growth in the building and construction sector with investments funding from the Chinese government over the years. The focus of this study is to ascertain whether Chinese FDI and the building and construction sector of Ghana have any linkages, and whether construction activities contribute to growth of Ghana's economy. These issues are of major concerns since Bon $(1988,1992)$ revealed that, as a nation's economy grows and develops, the mutuality between the construction sector and other sectors of the economy is not static but fluid.

\section{Theoretical Framework and Hypotheses}

Many researchers have studied the effects of construction industry on the economic growth from different aspects and drawn different conclusions. In summary there are three channels that the construction industry can affect the economic growth: 1 . Hirschman (1958) stated that, not all sectors have the same potential to absorb FDI or to create linkages with the rest of the economy, hence there could have limited effects in spurring growth in an economy; 2. Edmonds and Miles (1984) and Wells (1986) recognized that, the early stage of economic development in most developing economies is characterized by the demand for new construction products, and construction activities tend to be highest at the early stages of economic development and level off after high level of economic development has been attained; 3. Kirmani (1984) revealed that, the building and construction sector is an essential engine for the growth of an economy since inflows of FDI into this sector have become an essential source of both investment and technology transfer for most developing countries. Although the building and construction sector that serves as the base for infrastructural development of a given country attracts huge amounts of FDI, there is still a loophole as to how FDI affects the host country's economic growth (Lipsey, 2002). This paper will attempt to answer some questions as to how Chinese FDI affects Ghana's economic growth through direct and indirect effects in the building and construction sector. Some 
direct effects to be analyzed are the improvement in infrastructure: provision of housing facilities and construction of roads and ports helps alleviates distribution of goods and services within and outside a country. Employment growth: the improvement in the value creation in local products that happens to be a major contributor to national employment reduction and revenue generation. Also some indirect effects to be analyzed will be the provision of cost effective projects, and the execution of timely projects since this sector is a key social development contributor and thus the construction sector in particular will enjoy rapid growth as compared to the entire economy as there is a rapid demand of construction skills and technology. Based on these assumptions, the following hypotheses were derived:

Hypothesis 1: Chinese FDI flows affect economic growth through direct effects on building and construction sector of Ghana.

Hypothesis 2: Chinese FDI flows affect economic growth through indirect effects on building and construction sector of Ghana.

Although there are enormous advantages that a particular country can benefit from FDI inflows, some form of negativity could be associated to FDI inflows if the receiving country does not establish effective monitoring measures. Fleshman (2009) mention that, the challenges of FDI in the construction sector can be attributed to policy framework, corruption and insecurity of investment and so to achieve the full potential and benefits of FDI inflows, there is the need to provide check and balances to avoid the abuse of power and authority allocated to various government investment departments and agencies. In addition, Di Mauro (2000) stated that, FDI has the potential to benefit host countries and this is achievable if recipient FDI governments pursue adequate environmental policies and as a priority of every country especially dealing with the building and construction sector, it is important for governments to support and promote professionalism, adherence and proper training on health and safety in the execution of projects. Furthermore, Lankes and Venables (1996) posits that, host countries should closely monitor FDI from foreign entities as they can gain a monopolistic power and drive out domestic competitors out of business due to foreign entities access to finance and advanced technical and management expertise. It can be related to the low performance of domestic building and construction companies in Ghana as regular delays in government payments induce severe cash flow issues for domestic contractors. As governments all over the world are the largest clients in the building and construction industry, instituting monitoring mechanisms gives supervising departments and agencies the power to monitor, reward and punish unacceptable behaviors. Based on the above assumptions, the following hypothesis was formulated:

Hypothesis 3: Ghana's policies impact the effects of Chinese FDI activity in Hypothesis 1 and Hypothesis 2. 


\section{Nature of the Building and Housing Industry of Ghana}

The purpose of this section is to look at the tremendous demand for housing in Ghana due to population increase and the inability of government to make available to local building firms some supports like access to free lands and roads, provision of water and electricity, and most importantly, the facilitation of guaranteed loans. Although foreign firms' interest in the local building industry is encouraged, one can argue that, the country stands to gain more when the local building firms are provided with significant technical and financial support to enable them carry out big building projects.

The Ghana Statiscal Service (2012) revealed that, the population density of the country increased from 79 per square kilometer in 2000 to 103 per square kilometer in 2010. In addition, Graphic Online reported in 2013 that, the housing deficit was in excess of about 1.5 million units and despite the efforts of the government, private real estate developers and individuals in the provision of housing, there seems to be an acute shortage of housing units in the country (Adarkwa, 2012). It is imperative to critically investigate how Chinese FDI is contributing to solving Ghana's shortage of housing units and how it impacts on the operations of the local building industry. This can enable the local building industry to play a big role in closing the country's housing deficit (see table 1).

Table 1. Housing Demand, Supply and Deficit in Ghana, 1970 - 2000

\begin{tabular}{lcccc}
\hline Year & Population & Housing Demand & Housing Supply & Housing Deficit \\
\hline 1970 & 8559313 & 1678296 & 941639 & 736657 \\
1984 & 12296081 & 2410096 & 1226360 & 1184636 \\
2000 & 18912079 & 3708250 & 2181975 & 1526275 \\
\hline Average & 13735696 & 2693273 & 1561807 & 1131466 \\
\hline
\end{tabular}

Source: The average was Authors calculation based on data from United Nations - Habitat Report, 2011

\subsection{The Construction Industry of Ghana}

Regardless of the numerous contributions of the construction industry to the Ghanaian economy in terms of the provision of infrastructures such as roads, airports, and harbors especially for the transport sector, the industry is still underdeveloped due to the lack of a comprehensive policy framework. In addition, the Ministry of Roads and Highways of Ghana over the years has mainly focused its attention on road transport and unfortunately, its activities have not properly supported economic activities in the country. Ghana is among the many African countries to have gained positively from FDI and this has reflected in the construction of paved roads. By the definition of the International Road Federation, Paved Roads are those surfaced with crushed stone (macadam) and hydrocarbon binder, with concrete, as a percentage of all the country's roads, measured in length. The International Road Federation (2014) in its World Road Statistics and Electronic Files ranked Ghanaas the $156^{\text {th }}$ country in the world in 2010, with a 12.60 
value in paved roads as a percentage of total roads and the average paved roads (as a percentage of total roads) in Ghana, between 1990 and 2009, were just 21.61\% (Table 2).

Table 2.Paved Roads as a Percentage of Total Roads in Ghana, 1990-2009

\begin{tabular}{ccc}
\hline Year & Value $(\%)$ & Annual Change $(\%)$ \\
\hline 1990 & 19.6 & 0.00 \\
1991 & 23 & 17.35 \\
1992 & 23.5 & 2.17 \\
1993 & 23.9 & 1.70 \\
1994 & 24.4 & 2.09 \\
1995 & 24.9 & 2.05 \\
1996 & 24.1 & -3.21 \\
1999 & 29.6 & 22.82 \\
2000 & 29.6 & 0.00 \\
2001 & 18.4 & -37.84 \\
2003 & 17.92 & -2.61 \\
2005 & 14.9 & -16.85 \\
2008 & 16.1 & 8.05 \\
2009 & 12.6 & -21.74 \\
\hline Average & 21.61 & -2.00 \\
\hline
\end{tabular}

Source: The annual change was Authors calculation based on data from IRF World Road Statistics and Electronic Files, 2010

Table 2 shows that, Ghana's paved roads as a percentage of total roads in Ghana have continued to increase since 1990 through to 1995 at different values. The rise rate between 1990 and 1995 was about $25 \%$ and the drop rate was about $79 \%$ between 2001 and 2009. In 1996, the general presidential and parliamentary elections were held in Ghana and during this electioneering period, major maintenance and infrastructural projects are halted since all national funds are then diverted into the campaign of the incumbent government resulting in a decrease in value of paved roads from $24.9 \%$ in 1995 to $24.1 \%$ in 1996 . There was no change in the value of paved roads in 2000 , but the change of government in 2001 saw the new government abandoning, and failing to continue the maintenance of road projects especially paved roads. These actions resulted in a downward trend of value of paved roads in Ghana between 2001 and 2005 (18.4\% in $2001,17.92 \%$ in 2003 , and $14.9 \%$ in 2005$)$. However, there was an $8 \%$ increase in 2008 although that was an election year. This was a political strategy to show to the populace that, the incumbent government did not abandon projects of their predecessors. Interestingly, there was a decrease of about $22 \%$ in 2009 when there was again a change of government and the tradition of abandoning projects started by the previous government continued.

The International Road Federation defines Road Network to include motorways, highways, and all other roads (both national and regional) in a country. The minimum value of road network was recorded in 1991 with a total of $36,670 \mathrm{~km}$ 
and the maximum value of road network reached a high of $120,818 \mathrm{~km}$ in 2008 . The average total road network between 1990 and 2009 was about $52,191 \mathrm{~km}$. This is low in comparison with an average total road length of other countries such as South Africa $(362,099 \mathrm{~km}$ in 2002$)$, and Cote D'Ivoire $(80,000 \mathrm{~km}$ in 2006) (Table 3).

\section{Table 3. Total Road Network (km) in Ghana}

\begin{tabular}{ccc}
\hline Year & Value $(\mathrm{km})$ & Annual Change (\%) \\
\hline 1990 & 38,145 & 0.00 \\
1991 & 36,670 & -3.87 \\
1992 & 37,000 & 0.90 \\
1993 & 37,200 & 0.54 \\
1994 & 37,400 & 0.54 \\
1995 & 37,600 & 0.53 \\
1996 & 37,800 & 0.53 \\
1999 & 39,409 & 4.26 \\
2000 & 39,409 & 0.00 \\
2003 & 47,787 & 21.26 \\
2004 & 54,311 & 13.65 \\
2005 & 57,614 & 6.08 \\
2008 & 120,818 & 109.70 \\
2009 & 109,515 & -9.36 \\
\hline Average & 52,191 & 11.14 \\
\hline
\end{tabular}

Source: The annual change was Authors calculation based on data from IRF World Road Statistics and Electronic Files, 2010

Table 3 shows that, the totals of Ghana's road network experienced a decrease of about $4 \%$ in 1991 . This could be largely associated with the political atmosphere at that time since Ghana was under military rule and majority of the military junta's priorities did not include construction and maintenance of roads. However, the first of many free and fair elections conducted in 1992 to democratically elect a president and parliamentarians had some effect on the upward trend of road network in Ghana between 1992 and 2008 and at different values. However, there was a decrease of about $9 \%$ in 2009 which could be attributed to decrease in amounts allocated to the transport sector. If the government spent more on roads and at the expense of other sectors, the road network could have maintained its upward trend.

\subsection{Chinese Investment in Ghana's Building and Construction Sector}

The government of Ghana is the biggest employer undertaking the majority of the activities in the building and construction sector. However, Ghana has benefited vastly over the years from foreign direct investment flows in the building and construction sector and most notable foreign investing country is the People's Republic of China. Some completed projects with Chinese funding are: the University of Ghana Drama Studio, Dangbe East District Hospital, and an Office Complex for the Ministry of Defense. Chinese investments in the building and construction sector of Ghana reached a maximum value of USD 64.41 million in 
2010 and a minimum value of USD 60,000 in 2008. This sector recorded no changes in investments flows between 2000 and 2006. Plus, there have also been fluctuations in Chinese investments flow between 2003 and 2012. This is because, Chinese investments in Ghana were mostly in the manufacturing sector and so huge investments were diverted to boost the sector's operations. Interestingly there was relatively low or no interest in investments in the building and construction sector in the periods of 2000, 2004, 2008 and 2012 respectively. These periods were the elections years and since most foreign investors are always skeptical about the outcome of African countries elections, they tend to pull out or introduce a lukewarm attitude towards investments (Table 4).

Table 4. China's FDI Percentage Share in Ghana's Building and Construction Sector, $2000-2012$

\begin{tabular}{ccccccc}
\hline & $\begin{array}{c}\text { China's FDI } \\
(\mathrm{A})\end{array}$ & $\begin{array}{c}\text { Annual } \\
\text { Change }\end{array}$ & $\begin{array}{c}\text { Total FDI } \\
(\mathrm{B})\end{array}$ & $\begin{array}{c}\text { Annual } \\
\text { Change }\end{array}$ & $\begin{array}{c}\text { A \% Share } \\
\text { of B }\end{array}$ & $\begin{array}{c}\text { Annual } \\
\text { Change }\end{array}$ \\
\hline Year & $($ USDm) & $(\%)$ & $($ USDm) & $(\%)$ & $(\%)$ & $(\%)$ \\
\hline 2000 & 0.00 & 0.00 & 7.61 & 0.00 & 0.00 & 0.00 \\
2001 & 0.00 & 0.00 & 5.16 & -32.2 & 0.00 & 0.00 \\
2002 & 0.00 & 0.00 & 9.06 & 75.6 & 0.00 & 0.00 \\
2003 & 0.26 & 0.00 & 2.27 & -74.9 & 11.50 & 0.00 \\
2004 & 0.00 & 0.00 & 15.29 & 573.6 & 0.00 & 0.00 \\
2005 & 0.00 & 0.00 & 90.23 & 490.1 & 0.00 & 0.00 \\
2006 & 1.27 & 0.00 & 67.31 & -25.4 & 2.00 & 0.00 \\
2007 & 1.50 & 18 & 38.3 & -43.1 & 3.92 & 96 \\
2008 & 0.06 & -96 & $2,097.34$ & 5376.1 & 0.003 & -100 \\
2009 & 1.78 & 28.67 & 118.64 & -94.3 & 1.50 & 49900 \\
2010 & 64.41 & 35.19 & 123.06 & 3.7 & 52.34 & 3389 \\
2011 & 26.87 & -58 & 6067 & 4830.1 & 0.44 & -99 \\
2012 & 2.45 & -91 & $2,699.37$ & -55.5 & 0.09 & -80 \\
\hline
\end{tabular}

Source: The annual change was Authors calculation based on data from GIPC, 2013

\section{Research Methodology}

\subsection{Introduction}

The questionnaires were administered to stakeholders working in the Building and Construction Sector of Ghana comprising of Building Contractors, Civil Service Workers, Building Consultants, Construction Economists, and Investors. The respondents chosen had an in-depth understanding of foreign direct investments and its activities in economic sectors of Ghana specifically, the building and construction sector. Out of 200 questionnaires distributed, 99 responded comprising of 72 males and 27 females (49 of them were Building Contractors, 30 were Civil Service Workers, 10 were Investors, 6 were Construction Economists, and the remaining 4 were Building Consultants). Furthermore, 32 respondents had 10 years or less working experience, 41 respondents had between 11 and 15 years working experience, 12 respondents had between 16 and 20 years working 
experience, 9 respondents had between 21 and 25 years working experience, and 5 respondents had 26 or more years working experience.The questionnaire was structured in such a way that respondents will be able to answer it easily using the Seven-point Likert scale.

\subsection{Data Sources}

The focus of the study is to ascertain whether China's FDI has any link with Ghana's building and construction sector performance. Questionnaires were distributed to investigate how people perceive the influx of Chinese FDI in the building and construction sector and whether the Chinese FDI was having any effect in the sector. Chinese FDI in Ghana's Building and Construction Sector for the period 2000-2012 data were from Ghana Investment Promotion Centre reports (2013). Paved Roads as a Percentage of Total Roads in Ghana (1990-2009) and Total Road Network (km) in Ghana (1990-2009) data were obtained from the World Road Statistics and Electronic Files (2010) of the International Road Federation (IRF). Housing Demand, Supply and Deficit in Ghana (1970-2000) data were taken from the UN-Habitat Report (2011).

Table 5 shows the Pearson correlation independent variables identified in this study and the dependent variables (economic growth and increase in GDP). The improvement in infrastructure has the highest correlation value 0.65 with economic growth where aid in local capacity building has the highest correlation value of 0.59 with GDP growth. Interestingly, access to financial packages to local firms is the only variable that has the highest correlation with both economic growth and GDP growth at 0.51 and 0.53 respectively.

\section{Table 5. Results of theCorrelation Analysis}

\begin{tabular}{lcc}
\hline Dependent Variables & Economic Growth & GDP Increase \\
\hline Modern Infrastructure & 0.6508 & 0.4450 \\
Access to Financial Aid & 0.5124 & 0.5306 \\
Employment Increase & 0.3520 & 0.5813 \\
Supply of Low-Cost Projects & 0.2212 & 0.4135 \\
Occupational Health And Safety & 0.1656 & 0.2480 \\
Supply of Advance Infrastructure & 0.3054 & 0.4968 \\
Timely Projects Implementation & 0.2222 & 0.4309 \\
Assistance In Capacity Development & 0.3347 & 0.5922 \\
Efficient monitoring of investment & 0.3780 & 0.1003 \\
Access to policy model & 0.1639 & 0.1995 \\
Accountability scheme implementation & 0.1234 & 0.1751 \\
Training of personnel & 0.2022 & 0.1359 \\
Performance measurement & -0.0553 & 0.1897 \\
Execution of investment policies & 0.1305 & 0.2829 \\
\hline
\end{tabular}

Source: Authors calculation based on data from field survey, 2014

Among the independent variables identified in this study, only rewards and punishment to measure performance of foreign companies have a negative 
correlation with economic growth at 0.06 . Most of the independent variables have a significant relationship with the two dependent variables which means that, the independent variables under study contributes to both economic growth and GDP growth.

\subsection{Linear Regression}

The general form of the linear regression model used is:

$\mathrm{Y}=\mathrm{A}+\mathrm{B}_{1} \mathrm{X}_{1}+\ldots \ldots+\mathrm{B}_{\mathrm{n}} \mathrm{X}_{\mathrm{n}}+\varepsilon$

Where $X$ is the explanatory variable and $Y$ is the dependent variable. $B$ is the regression coefficients, and $\varepsilon$ is an error.

\section{Table 6. Definition of Variables}

\begin{tabular}{|c|c|c|c|}
\hline Variable & Label & Variable & Label \\
\hline ECG & Economic Growth (Dependent) & TPI & Timely Projects Implementation \\
\hline GDPI & GDP Increase (Dependent) & $A C D$ & Assistance In Capacity Development \\
\hline MIF & Modern Infrastructure & EMI & Efficient monitoring of investment \\
\hline AFA & Access to Financial Aid & APM & Access to policy model \\
\hline EIN & Employment Increase & ASI & $\begin{array}{l}\text { Accountability scheme } \\
\text { implementation }\end{array}$ \\
\hline SLP & Supply of Low-Cost Projects & TOP & Training of personnel \\
\hline $\mathrm{OHS}$ & Occupational Health And Safety & PEM & Performance measurement \\
\hline SAI & $\begin{array}{l}\text { Supply of Advance } \\
\text { Infrastructure }\end{array}$ & EIP & Execution of investment policies \\
\hline
\end{tabular}

This study follows the hypothesis 1 and test for the direct impact of Chinese foreign direct investment on economic growth through direct effects on building and construction sector of Ghana based on the following estimation model:

$$
\begin{aligned}
& \mathrm{ECG}=\mathrm{A}+\mathrm{B}_{1} \mathrm{MIF}+\mathrm{B}_{2} \mathrm{AFA}+\mathrm{B}_{3} \mathrm{EIN}+\varepsilon \\
& \mathrm{GDPI}=\mathrm{A}+\mathrm{B}_{1} \mathrm{MIF}+\mathrm{B}_{2} \mathrm{AFA}+\mathrm{B}_{3} \mathrm{EIN}+\varepsilon
\end{aligned}
$$

Where the list of independent variables includeMIF - Modern Infrastructure, AFA Access to Financial Aid, and EIN- Employment Increase. The results of the estimation are in Table 7.

Table 7. Results of the Effects of Chinese FDI on Economic Growth through Direct Effects on Ghana's Buildings and Construction Sector

\begin{tabular}{lll}
\hline Dependent Variable: & Economic Growth & GDP Increase \\
\hline Modern Infrastructure & $0.496(6.11)^{* *}$ & $0.230(2.33)^{*}$ \\
Access to financial aid & $0.218(2.44)^{*}$ & $0.145(1.34)$ \\
Employment Increase & $-0.032(0.44)$ & $0.330(3.67)^{* *}$ \\
Constant & $1.358(3.88)^{* *}$ & $1.098(2.58)^{*}$ \\
Observations & 99 & 99 \\
R-squared & 0.48 & 0.40 \\
\hline
\end{tabular}

Note: *=significant at the $5 \%$ level; ${ }^{* *}=$ significant at the $1 \%$ level; absolute value of $t$ statistics in parentheses. Source: Authors calculation based on data from field survey, 2014 
Table 8 shows the results of the regression for hypothesis 1 . The regression analysis shows the relationship between independent variables and dependent variables. Employment increase in column (1) has a negative effective on economic growth with coefficient -0.032 . This means that, rapid employment generation does not translate into economic growth. Also, modern infrastructure and access to financial aid in column (1) has a direct impact on economic growth with coefficients 0.496 and 0.218 respectively. Modern infrastructure and access to financial aid in column (2) both has a direct impact on national GDP with coefficients 0.230 and 0.145 respectively. Employment increase has the highest coefficient at 0.33 and it is significant at one percent level. Furthermore, the independent variables have 48 percent and 40 percent influence on the dependent variable in columns (1) and (2) respectively. The robustness of this model showed that, $63 \%$ of the 8 models generated positive and significant coefficient estimates. The robustness t-statistic is 1.5159 indicating that the positive effect of Chinese FDI on economic growth through direct effects on Ghana's buildings and construction sector is a robust conclusion.

\section{Table 8. Results of Model Robustness of Hypothesis 1 based on Robust} Regression

\begin{tabular}{lrll}
\hline Variable of interest & GDPI & & \\
\hline Outcome variable & ECG & Number of observations & 99 \\
\hline Possible control terms & 3 & Mean R-squared & 0.36 \\
\hline Number of models & 8 & Multicollinearity & 0.41 \\
\hline Model Robustness Statistics: & & Significance Testing: & \\
\hline Mean(b) & 0.2099 & Sign Stability & $100 \%$ \\
\hline Sampling SE & 0.0909 & Significance rate & $63 \%$ \\
\hline Modeling SE & 0.1045 & Positive & $100 \%$ \\
\hline Total SE & 0.1385 & Positive and Sig & $63 \%$ \\
\hline Robustness Ratio: & 1.5159 & Negative & $0 \%$ \\
\hline & & Negative and Sig & $0 \%$ \\
\hline
\end{tabular}

Note: sample size varies across model specifications; Listwise deletion: 25 out of 124 observations will not be used.

We then look at the hypothesis 2 and test for the direct impact of Chinese foreign direct investment on economic growth through indirect effects on building and construction sector of Ghana based on the following estimation model:

$$
\begin{aligned}
& \mathrm{ECG}=\mathrm{A}+\mathrm{B}_{1} \mathrm{SLP}+\mathrm{B}_{2} \mathrm{OHS}+\mathrm{B}_{3} \mathrm{SAI}+\mathrm{B}_{4} \mathrm{TPI}+\mathrm{B}_{5} \mathrm{ACD}+\varepsilon \\
& \mathrm{GDPI}=\mathrm{A}+\mathrm{B}_{1} \mathrm{SLP}+\mathrm{B}_{2} \mathrm{OHS}+\mathrm{B}_{3} \mathrm{SAI}+\mathrm{B}_{4} \mathrm{TPI}+\mathrm{B}_{5} \mathrm{ACD}+\varepsilon
\end{aligned}
$$

Where the list of independent variables includeSLP - Supply of Low-Cost Projects, OHS - Occupational Health and Safety, SAI - Supply of Advance Infrastructure, TPI Timely Projects Implementation, ACD - Assistance In Capacity Development. The results of the estimation are shown in Table 9. 
Table 9. Results of the effects of Chinese FDI on economic growth through indirect effects on Ghana's buildings and construction sector

\begin{tabular}{lll}
\hline Dependent Variable: & Economic Growth & GDP Increase \\
\hline Supply of Low-Cost Projects & $0.060(0.50)$ & $0.062(0.55)$ \\
Occupational Health And Safety & $-0.021(0.19)$ & $-0.104(0.96)$ \\
Supply of Advance Infrastructure & $0.187(1.57)$ & $0.216(1.94)$ \\
Timely Projects Implementation & $-0.031(0.27)$ & $0.088(0.81)$ \\
Assistance In Capacity Development & $0.235(2.34)^{*}$ & $0.451(4.78)^{* *}$ \\
Constant & $2.426(4.87)^{* *}$ & $1.040(2.23)^{*}$ \\
Observations & 99 & 99 \\
R-squared & 0.19 & 0.42 \\
\hline
\end{tabular}

Note: ${ }^{*}=$ significant at the $5 \%$ level; ${ }^{* *}=$ significant at the $1 \%$ level; absolute value of $\mathrm{t}$ statistics in parentheses. Source: Authors calculation based on data from field survey, 2014

The results of the robust regression in table 10 for hypothesis 2 suggests that there is a much lower relationship between the independent and dependent variables. The occupational health and safety and the timely projects implementation in column (1) has a negative effective on economic growth with coefficients -0.021 and 0.235 respectively. However, in column (2), the timely projects implementation variable had a positive influence on GDP. This means that, when contracted projects are completed on time and used for its purpose, the government is able to significantly measure the total market values of goods and services produced by workers and capital. Furthermore, it shows in column (1) and (2) that, Chinese FDI positively affects the economic growth and increases GDP through the building of local workforce knowledge and capacity building with a co-efficient value of 0.235 which is significant at five percent level and the highest regression co-efficient value of 0.451 and it is significant at one percent level in both columns (1) and (2) respectively. This means that, Chinese FDI contribution to the local capacity development provides more room for efficiency and less room for mismanaged works.

Table 10. Results of Model Robustness of Hypothesis $\mathbf{2}$ based on Robust Regression

\begin{tabular}{lrll}
\hline Variable of interest & GDPI & & \\
\hline Outcome variable & ECG & Number of observations & 99 \\
\hline Possible control terms & 5 & Mean R-squared & 0.22 \\
\hline Number of models & 32 & Multicollinearity & 0.43 \\
\hline Model Robustness Statistics: & & Significance Testing: & \\
\hline Mean(b) & 0.3147 & Sign Stability & $100 \%$ \\
\hline Sampling SE & 0.1038 & Significance rate & $100 \%$ \\
\hline Modeling SE & 0.0373 & Positive & $100 \%$ \\
\hline Total SE & 0.1103 & Positive and Sig & $100 \%$ \\
\hline Robustness Ratio: & 2.8534 & Negative & $0 \%$ \\
\hline & & Negative and Sig & $0 \%$ \\
\hline
\end{tabular}

Note: sample size varies across model specifications; Listwise deletion: 25 out of 124 observations will not be used. 
An efficient workforce benefits an economy from high productivity and leads to growth in individual household incomes. In a situation like this, the citizens contribute income tax and this enables economic progression and development. However, the independent variables have 19 percent and 42 percent influence on the dependent variable in columns (1) and (2) respectively. And this shows that, the independent variable does not have a significant influence on economic growth. The robustness of this model showed that, $100 \%$ of the 32 models generated positive and significant coefficient estimates. The robustness t-statistic is 2.8534 indicating that, the positive effect of Chinese FDI on economic growth through indirect effects on Ghana's buildings and construction sector is a robust conclusion (Table 10).

The study further looks at the hypothesis 3 and test for the government of Ghana policies affecting the impact of foreign direct investment state in hypothesis 1 and hypothesis 2 based on the following estimation model:

$$
\begin{gathered}
\mathrm{ECG}=\mathrm{A}+\mathrm{B}_{1} \mathrm{MIF}+\mathrm{B}_{2} \mathrm{AFA}+\mathrm{B}_{3} \mathrm{EIN}+\mathrm{B}_{4} \mathrm{EMI}+\mathrm{B}_{5} \mathrm{APM}+\mathrm{B}_{6} \mathrm{ASI}+\mathrm{B}_{7} \mathrm{TOP} \\
+\mathrm{B}_{8} \mathrm{PEM}+\mathrm{B}_{9} \mathrm{EIP}+\varepsilon \\
\mathrm{GDPI}=\mathrm{A}+\mathrm{B}_{1} \mathrm{MIF}+\mathrm{B}_{2} \mathrm{AFA}+\mathrm{B}_{3} \mathrm{EIN}+\mathrm{B}_{4} \mathrm{EMI}+\mathrm{B}_{5} \mathrm{APM}+\mathrm{B}_{6} \mathrm{ASI}+\mathrm{B}_{7} \mathrm{TOP} \\
+\mathrm{B}_{8} \mathrm{PEM}+\mathrm{B}_{9} \mathrm{EIP}+\varepsilon
\end{gathered}
$$

Where the list of independent variables includeMIF - Modern Infrastructure, AFA Access to Financial Aid, EIN- Employment Increase, EMI -Efficient monitoring of investment, APM - Access to policy model, ASI -Accountability scheme implementation, TOP - Training of personnel, PEM - Performance measurement, EIP - Execution of investment policies

$$
\begin{gathered}
\mathrm{ECG}=\mathrm{A}+\mathrm{B}_{1} \mathrm{SLP}+\mathrm{B}_{2} \mathrm{OHS}+\mathrm{B}_{3} \mathrm{SAI}+\mathrm{B}_{4} \mathrm{TPI}+\mathrm{B}_{5} \mathrm{ACD}+\mathrm{B}_{6} \mathrm{EMI}+\mathrm{B}_{7} \mathrm{APM} \\
+\mathrm{B}_{8} \mathrm{ASI}+\mathrm{B}_{9} \mathrm{TOP}+\mathrm{B}_{10} \mathrm{PEM}+\mathrm{B}_{11} \mathrm{EIP}+\varepsilon \\
\mathrm{GDPI}=\mathrm{A}+\mathrm{B}_{1} \mathrm{SLP}+\mathrm{B}_{2} \mathrm{OHS}+\mathrm{B}_{3} \mathrm{SAI}+\mathrm{B}_{4} \mathrm{TPI}+\mathrm{B}_{5} \mathrm{ACD}+\mathrm{B}_{6} \mathrm{EMI}+\mathrm{B}_{7} \mathrm{APM} \\
+\mathrm{B}_{8} \mathrm{ASI}+\mathrm{B}_{9} \mathrm{TOP}+\mathrm{B}_{10} \mathrm{PEM}+\mathrm{B}_{11} \mathrm{EIP}+\varepsilon
\end{gathered}
$$

Where the list of independent variables include SLP - Supply of Low-Cost Projects, OHS - Occupational Health and Safety, SAI - Supply of Advance Infrastructure, TPI Timely Projects Implementation, ACD - Assistance In Capacity Development, EMI Efficient monitoring of investment, APM - Access to policy model, ASI Accountability scheme implementation, TOP - Training of personnel, PEM Performance measurement, EIP - Execution of investment policies

Table 11 shows the results of the regression for hypothesis 3. The regression analysis shows the relationship between government policies and the impact of Chinese FDI in Ghana's building and construction sector through both direct and indirect effects. The modern infrastructure variable had the highest regression coefficient with economic growth at 0.430 and it is significant at one percent level. This means that, when government policies shapes the direction of FDI and channels FDI to the right projects, it benefits the common people. 
Kwasi BOAKYE-GYASI \& Yao LI

Table 11. Results of the Government of Ghana policies affecting the impact of FDI state in hypothesis 1 and hypothesis 2

\begin{tabular}{|c|c|c|c|c|}
\hline Dependent Variable: & $\begin{array}{l}\text { Economi } \\
\text { c Growth }\end{array}$ & $\begin{array}{c}\text { GDP } \\
\text { Increase }\end{array}$ & $\begin{array}{c}\text { Economic } \\
\text { Growth }\end{array}$ & $\begin{array}{c}\text { GDP } \\
\text { Increase }\end{array}$ \\
\hline & (1) & (2) & (3) & (4) \\
\hline Modern Infrastructure & $\begin{array}{c}0.430 \\
(4.85)^{* *}\end{array}$ & $\begin{array}{l}0.189 \\
(1.65)\end{array}$ & & \\
\hline Access to Financial Aid & $\begin{array}{c}0.276 \\
(3.11)^{* *}\end{array}$ & $\begin{array}{l}0.157 \\
(1.37)\end{array}$ & & \\
\hline Employment Increase & $\begin{array}{r}-0.043 \\
(0.58)\end{array}$ & $\begin{array}{c}0.377 \\
(3.93)^{* *}\end{array}$ & & \\
\hline Efficient monitoring of investment & $\begin{array}{c}0.246 \\
(2.58)^{*}\end{array}$ & $\begin{array}{l}-0.230 \\
(1.87)\end{array}$ & $\begin{array}{c}0.356 \\
(2.76)^{* *}\end{array}$ & $\begin{array}{l}-0.059 \\
(0.47)\end{array}$ \\
\hline Access to policy model & $\begin{array}{l}-0.043 \\
(0.42)\end{array}$ & $\begin{array}{l}0.208 \\
(1.56)\end{array}$ & $\begin{array}{r}-0.097 \\
(0.68)\end{array}$ & $\begin{array}{l}0.039 \\
(0.28)\end{array}$ \\
\hline Accountability scheme implementation & $\begin{array}{l}-0.069 \\
(0.65)\end{array}$ & $\begin{array}{l}0.105 \\
(0.77)\end{array}$ & $\begin{array}{l}-0.136 \\
(0.95)\end{array}$ & $\begin{array}{l}0.024 \\
(0.17)\end{array}$ \\
\hline Training of personnel & $\begin{array}{l}0.070 \\
(0.77)\end{array}$ & $\begin{array}{l}-0.131 \\
(1.12)\end{array}$ & $\begin{array}{l}0.067 \\
(0.52)\end{array}$ & $\begin{array}{l}-0.093 \\
(0.73)\end{array}$ \\
\hline Performance measurement & $\begin{array}{l}-0.081 \\
(0.88)\end{array}$ & $\begin{array}{l}-0.157 \\
(1.32)\end{array}$ & $\begin{array}{l}-0.126 \\
(1.16)\end{array}$ & $\begin{array}{l}0.010 \\
(0.09)\end{array}$ \\
\hline Execution of investment policies & $\begin{array}{l}-0.080 \\
(1.05)\end{array}$ & $\begin{array}{c}0.210 \\
(2.13)^{*}\end{array}$ & $\begin{array}{l}0.054 \\
(0.50)\end{array}$ & $\begin{array}{l}0.150 \\
(1.41)\end{array}$ \\
\hline Supply of Low-Cost Projects & & & $\begin{array}{l}-0.018 \\
(0.14)\end{array}$ & $\begin{array}{l}0.022 \\
(0.17)\end{array}$ \\
\hline Occupational Health And Safety & & & $\begin{array}{l}-0.023 \\
(0.18)\end{array}$ & $\begin{array}{l}-0.096 \\
(0.79)\end{array}$ \\
\hline Supply of Advance Infrastructure & & & $\begin{array}{l}0.213 \\
(1.65)\end{array}$ & $\begin{array}{c}0.280 \\
(2.23)^{*}\end{array}$ \\
\hline Timely Projects Implementation & & & $\begin{array}{l}-0.021 \\
(0.18)\end{array}$ & $\begin{array}{l}0.083 \\
(0.73)\end{array}$ \\
\hline Assistance In Capacity Development & & & $\begin{array}{l}0.198 \\
(1.80)\end{array}$ & $\begin{array}{c}0.389 \\
(3.63)^{* *}\end{array}$ \\
\hline Constant & $\begin{array}{c}1.341 \\
(3.35)^{* *}\end{array}$ & $\begin{array}{l}0.936 \\
(1.81)\end{array}$ & $\begin{array}{c}2.355 \\
(4.14)^{* *}\end{array}$ & $\begin{array}{l}0.886 \\
(1.60)\end{array}$ \\
\hline Observations & 99 & 99 & 99 & 99 \\
\hline R-squared & 0.57 & 0.45 & 0.27 & 0.43 \\
\hline
\end{tabular}

Note: ${ }^{*}=$ significant at the $5 \%$ level; ${ }^{* *}=$ significant at the $1 \%$ level; absolute value of $\mathrm{t}$ statistics in parentheses. Source: Authors calculation based on data from field survey, 2014

Table 7 further shows us that, the independent variables have 57 percent, 45 percent, 27 percent and 43 percent influence on the dependent variables in columns (1), (2), (3) and (4) respectively. Although these values may seem to be insignificant, it can be deduced that, robust regression helps eliminates all outliners and give us an absolute value. The robustness of this model showed that, $100 \%$ of the 2,048 models generated positive and significant coefficient estimates. The robustness t-statistic is 3.1227 indicating that, the positive effect of government 
policies affecting the impact of foreign direct investment state in hypothesis 1 and hypothesis 2 is a robust conclusion (Table 12).

\begin{tabular}{|c|c|c|c|}
\hline Variable of interest & GDPI & & \\
\hline Outcome variable & ECG & Number of observations & 99 \\
\hline Possible control terms & 11 & Mean R-squared & 0.28 \\
\hline Number of models & 2,048 & Multicollinearity & 0.45 \\
\hline Model Robustness Statistics: & & Significance Testing: & \\
\hline Mean(b) & 0.3414 & Sign Stability & $100 \%$ \\
\hline Sampling SE & 0.1033 & Significance rate & $100 \%$ \\
\hline Modeling SE & 0.0359 & Positive & $100 \%$ \\
\hline Total SE & 0.1093 & Positive and Sig & $100 \%$ \\
\hline \multirow[t]{2}{*}{ Robustness Ratio: } & 3.1227 & Negative & $0 \%$ \\
\hline & & Negative and Sig & $0 \%$ \\
\hline
\end{tabular}

Note: sample size varies across model specifications; Listwise deletion: 25 out of 124 observations will not be used.

\section{Conclusion}

This study was looking at the link between China's FDI and Ghana's building and construction sector performance and it was revealed that, there is a positive and high significance on economic growth through direct effects. Also, Chinese FDI has a negative effective on growth through increase in employment whilst its improvement in infrastructure and access to financial packages has a positive and high significant effect on economic growth. The understanding is that, FDI contributes to economic growth when there is an improvement of the infrastructure and operational skills of the local building and construction companies. This will lead to the increase in revenue for citizens who are employed in this sector and thus leading to the overall economic development of the country. The study further showed that, Chinese foreign direct investment flows in Ghana's building and construction sector through indirect effects have a much lower relationship with economic growth. However, Chinese FDI contribution to the local capacity building which is an indirect factor provides more room for efficiency and less room for poorly done works.

Furthermore, through both direct and indirect effects, the effects of Chinese FDI and Ghana's building and construction sector performance had a relationship with government policies. The implementation of monitoring mechanisms by government and institutional supervising bodies will help evaluate inflow of foreign investments, and this enables governments to ascertain whether foreign companies abide by the stipulated investment regulations. Also, the government can build capable human resource sector due to the benefits of FDI influx resulting in knowledge transfer. Since it is crucial to ascertain the validity and reliability of this study for the dependency of future works, the results also shown that, the 
addition of increase in gross domestic product as a determinant variable for economic growth revealed the robustness of the results notwithstanding the data employed. Notwithstanding the findings of this study, it highly recommended that, sample size should be widened, geographical focus could be enlarged to include other countries, and a comprehensive micro level study can reveal meaningful insights.

\section{Acknowledgement}

The authors are grateful to the Ghana Investment Promotion Centre for sharing data, Lenka Saerang, Owusu Ackah, David Agbee Searyoh, Rocio Fisher and beloved family and friends for valuable comments, suggestions and support. But the authors reserve to themselves the responsibility for any errors. This paper is dedicated to Mr. P.K. Gyasi and Mrs. Comfort N. Gyasi. God richly bless you all.

\section{References}

Adarkwa, K.K. (2012). The Changing Face of Ghanaian Towns. African Review of Economics and Finance, 4 (1): 1-29.

Bon, R. (1988). Direct and Indirect Resource Utilization by the Construction Sector: The Case of the USA since World War II, Habitat International, 12 (1), 49-74. Doi: 10.1016/01973975(88)90039-2

Bon, R. (1992). The Future of International Construction: Secular Patterns of Growth and Decline. Habitat International, 16(3), 119-28. Doi: 10.1016/0197-3975(92)90068-A

Borensztein, E., De Gregorio, J., \& Lee, J-W. (1998). How Does Foreign Direct Investment Affect Economic Growth? Journal of International Economics, 45, 115-135. Doi: 10.1016/S0022-1996(97)00033-0

Di Mauro, F. (2000). The Impact of Economic Integration on FDI and Exports. Economic Journal, 156: 90-97.

Edmonds, G.A., \& Miles, D.W.J. (1984). Foundations for Change: Aspects of the Construction Industry in Developing Countries. London: Intermediate Technology Publications Ltd. Doi: 10.3362/9781780442242

Fleshman, M. (2009). Laying Africa's roads to prosperity. New York: United Nations. Retrieved on February 15, 2016, from Africa Renewal website:http://www.un.org/africarenewal/magazine/january-2009/layingafrica\%E2\%80\%99s-roads-prosperity.

Ghana Investment Promotion Council (2013). $1^{\text {st }}$ Quarter Investment Reports. Retrieved on June 28, 2014, from http://www.gipcghana.com/press-and-media/downloads/category/112013.html

Ghana Statiscal Service (2012). 2010 Population and Housing Census May Report. Accra: Ghana Statistical Service.

Graphic Online (2013, March 4). Human Rights Education and Capacity Building, Slums and Forced Eviction. Retrieved on June 28, 2015, from Graphic Online website:http://www.modernghana.com/news/449588/1/ministry-drafts-new-housingpolicy.html. 
The Linkage between China's Foreign Direct Investment and Ghana's Building and ...

Hirschman, A.O. (1958). The Strategy of Economic Development. New Haven: Yale University Press.

Institute for Economics and Peace, (2012). Global Peace Index rankings. Retrieved on September 30, 2015, from Wikipedia website: https://en.wikipedia.org/wiki/Global_Peace_Index.

International Monetary Fund (1993). Balance of Payments Manual, 5th edition. Washington D.C.: International Monetary Fund, 1993.

International Road Federation (2014). World Road Statistics and Electronic Files. Geneva: International Road Federation

Kirmani, S. (1984). The Construction Industry in Development: Issues and Options. Washington D.C.: World Bank.

Lankes, H.P. \&Venables, A.J. (1996). Foreign Direct Investment in Economic Transition: The

Changing Pattern of Investment. Economics of Transition, 4: 331-347. https://doi.org/10.1111/j.1468-0351.1996.tb00176.x

Lean, S.C. (2001). Empirical tests to discern linkages between construction and other economic sectors in Singapore. Construction Management and Economics, 13, 253262.https://doi.org/10.1080/01446190010022686

Lipsey, R.E. (2002). Home and Host Country Effects of FDI. Working Paper No. 9293. Cambridge, M.A.: National Bureau of Economic Research. Retrieved on September 15, 2015, from National Bureau of Economic Research website: http://www.nber.org/papers/w9293.https://doi.org/10.3386/w9293

Mosaku, T.O., Kehinde, J.O., \& Kuroshi, P.A. (2006). Control of Building Practice for Sustainable Development in Nigeria: Matters Arising. Proceedings of the International Conference on the Built Environment; Innovation, Policy and Sustainable Development. Department of Architecture, Covenant University, Ota, Nigeria, 24-26 January, pp. 26-33.

Rameezdeen, R., Nisa. Z., \& Ramach, T. (2006). Study of Linkages between Construction Sector and Other Sectors of the Sri Lankan Economy. Department of Building Economics, University of Moratuwa, Sri Lanka.

Sauvant, K.P. (2007). Foreign Direct Investment Opportunities in Africa. Retrieved on September 30, 2015, from Craig Eisele Word Press website: https://craigeisele.wordpress.com/2007/09/02/foreign-direct-investment-opportunities-inafrica/.

UNCTAD (2008). World Investment Report: Transnational Corporations and the Infrastructure Challenge. New York: United Nations Conference on Trade and Development

Wells, J. (1986). The Construction Industry in Developing Countries: Alternate Strategies for Development. London: Croom Helm Ltd. 